\title{
Mitä on väestötiede?
}

\author{
Kirjoittanut Reino Lento.
}

Eräissä tämän julkaisun kirjoituksissa esiintyvä nimitys "väestötiede" saattaa tuntua monesta lukijasta oudolta ja sen edustama käsite hämärältä. Mikäli hakuteosten avulla pyritään luomaan asiaan lisävalaistusta, saadaan todeta, että esim. Iso tietosanakirjamme ei tällaista sanaa lainkaan tunne. Sen sijaan sieltä on löydettävissä hakusana "väestöoppi», joka määritellään seuraavasti: "Väestöoppi, demografia, tiede, joka käsittelee väestön tilaa ja muutoksia sekä sinänsä että yhteiskunnallisten, taloudellisten ja biologisten tekijöiden yhteydessä. Väestöoppi perustuu lähinnä väestötilastoon ja on erikoisesti viime aikoina kehittynyt itsenäiseksi tieteeksi valtio- eli yhteiskuntatieteiden ryhmässä — — - ,

Tämän määritelmän mukaan väestöoppi siis on tiede. Kysymyksen ollessa nuoresta tieteestä on ymmärrettävää, että se on vielä verraten vähän tunnettu ja että käsitykset sen tehtävistä ja työkentästä ovat vielä varsin epämääräiset ja kehityksenalaiset. Sama koskee myöskin sen terminologiaa. Etenkin tämän alan suomenkielinen nimistö on vielä vakiintumaton, ja kun se yleensä on suoranaista käännöstä vieraista kielistä, se ei aina ole suomenkielen vaatimuksia vastaavaa.

Viimeksimainittu puutteellisuus ilmenee esim. itse tieteen nimessä. "Väestöoppi» on kyllä tarkka vastine ruotsin ja saksan vastaaville nimityksille »befolkningslära» ja »Bevölkerungs- 
lehre», mutta sitä ei silti voida pitää onnistuneena. Suomessa »oppi»-sanaa on tavallisesti käytetty koulukirjojen nimissä (esim. eläinoppi, kasvioppi, mittausoppi jne.) taikka tarkoittamaan sellaisia esityksiä, joiden tehtävänä on selostaa jonkin tiedonalan pääkohdat mahdollisimman helppotajuisessa muodossa ja lähinnä käytännöllisen elämän tarpeita varten (esim. kauppaoppi, teollisuuden liikkeenhoito-oppi, ehtolyhennysoppi ym.). Tämän sanan käyttö tieteen nimessä on sensijaan omiaan alentamaan ko. tieteen arvoa. Jos väestöoppi kerran tunnustetaan tieteeksi, silloin on syytä myös käyttää siitä tieteen nimeä. Vaikka esim. saksankielessä onkin käytetty "-lehre» sanaa rinnan "-wissenschaft"-lopun kanssa, ei meidän ole syytä seurata esimerkkiä, etenkin kun saksassakin »Finanzwissenschaft» näyttää yhä enemmän syrjäyttävän »Finanzlehren» ja "Bevölkerungswissenschaft» »Bevölkerungslehre'n»'. Onhan saksan "Volkswirtschaftslehre'nkin" vastineena suomessa aina ollut "kansantaloustiede" eikä "kansantalousoppi». Mai-" nittakoon samalla, että nimitystä »väestötiede» on Leo Harmaja käyttänyt jo v. 1939 julkaisemassaan »Tilastotieteen oppikirjassa” (s. 13).

Edellä mainitussa väestöopin määritelmässä esiintyy myös sana "demografia», joka on yleinen etenkin romaanisissa kielissä. Sen otti ensimmäisenä käytäntöön Achille Guillard v. 1855 julkaisemassaan teoksessa »Eléments de statistique humaine, ou démographie comparée». Siinä hän määritteli demografian »ihmissuvun luonnon- ja sosiaaliseksi historiaksi» sekä suppeammassa mielessä »matemaattiseksi tiedoksi väestöstä, sen yleisistä muutoksista, sen fyysillisestä, älyllisestä, yhteiskunnallisesta (civil) ja siveellisestä tilastan.? Myöhemmin tälle sanalle on annettu moniakin eri merkityksiä, ${ }^{3}$ mutta tavallisimmin sillä on tarkoitettu väestötilastoa ${ }^{4}{ }^{\text {joksi se tietosanakirjas- }}$ sammekin selitetään. ${ }^{5}$ Viime aikoina on sanaa »démographie» alettu kuitenkin varsinkin Ranskassa käyttää yhä yksinomaisemmin väestötiedettä tarkoittamaan. ${ }^{6}$

Mutta, voidaan kysyä, mikä ero sitten on väestötilastolla ja väestötieteellä? Eikö väestötilasto, pitäessään kirjaa synty- 
misistä ja kuolemantapauksista, avioliitoista ja väestön jakaantumisesta erilaisten tunnusmerkkien mukaan, samalla kykene osoittamaan ne säännönmukaisuudet, joita väestön tilassa ja sen muutoksissa mahdollisesti on todettavissa, ja ne kehityssuunnat, joihin kulloinkin ollaan kulkemassa? Tarvitaanko mitään erikoista väestötiedettä?

On myönnettävä, että väestötilasto ei ole pelkkää tosiasioiden ja ilmiöiden toteamista ja kuvailua, vaan että sen tehtävä ulottuu laajemmallekin. Tilastojulkaisuissa on tapana esim. verrata syntyneiden ja kuolleiden lukua koko väkilukuun tai sen yksityisiin ryhmiin ja siten osoittaa eri lukusarjojen keskinäiset suhteet. Mutta näiden ilmiöiden tarkempi selvitteleminen vaatii muitakin tietoja, kuin mitä väestötilasto sisältää, ja hienompia menettelytapoja, kuin mihin sillä on mahdollisuuksia. Niinpä esim. ne hedelmällisyys- ja uusiutumisluvut, joita viime aikoina on alettu yhä enemmän käyttää tavanmukaisen karkeasti lasketun syntyneisyysluvun asemesta, kuuluvat jo tieteen piiriin, samoin myös ne ennakkolaskelmat eri maiden tulevasta väestönkehityksestä eli väestöprognoosit, joissa väestötilastollisten kuolleisuustaulujen ohella on käytettävä apuna syntyneiden luvun tai hedelmällisyyden tulevaa kehitystä koskevia otaksumia.

Väestötilaston ja väestötieteen välinen ero ilmenee myös siinä, että viimeksi mainitun ei aina eikä yksinomaisesti tarvitse perustua edellisen antamalle aineistolle. Esim. Malthuksen kuuluisa väestölaki sai oikeastaan alkunsa niistä yleisistä huomioista, joita hän teki väestön lisääntymistendenssistä oman aikansa Englannissa ja joita hän sitten myöhemmin pyrki todistelemaan tilastoaineiston avulla. Väestötiede ei suinkaan aina saa väestötilastolta kaikkia niitä tietoja, joita se tarvitsisi. Väestötieteen ja väestötilaston välisessä yhteistyössä ei ensiksi mainittu aina ole yksinomaan vastaanottavana osapuolena, vaan se voi myöskin puolestaan olla hyödyksi väestötilastolle antamalla viitteitä siitä, mihin suuntaan viimeksi mainittua olisi kehitettävä, jotta se entistä paremmin kykenisi täyttämään tehtävänsä. 
Sen suuren merkityksen perusteella, mikä väestötilastolla väestöolojen tuntemiselle on, väestöoppi eli -tiede on tavallisesti jaettu kolmeen osaan: väestötilastoon, väestöteoriaan ja väestöpolitiikkaan. Ensiksi mainitun tehtäväksi on määritelty tutkimusta varten tarpeellisten tosiasioiden kerääminen, kun taas väestöteorialle kuuluu niiden selvittäminen ja väestöpolitiikalle ne toimenpiteet, jotka ovat omiaan määrätyllä tavalla vaikuttamaan väestön tilaan ja kehitykseen. ${ }^{7}$ Tätä kolmijakoa asettui jo viime vuosisadalla vastustamaan Gustav Rümelin, joka osoitti, että väestötilaston edustama asiaintilan toteaminen ei voi olla väestöteoriaan ja -politiikkaan nähden tasaarvoinen ja niihin rinnastettava jäsen, vaan että sitä on pidettävä näiden aputieteenä, joka tarjoaa aineistoa koko tutkimukselle, samaan tapaan kuin lähdetutkimus ei ole historiankirjoitukseen rinnastettava vaan sille alistettu. ${ }^{8}$ Samalle kannalle kuin Rümelin asettuvat tässä asiassa myös esim. Adolf Wagner ${ }^{9}$, Otto Most ${ }^{10}$ ja Paul Mombert. ${ }^{11}$ Väestötilasto on, kuten viimeksi mainittu huomauttaa, väestöteorian kannalta vain metodi, tutkimuksen apuneuvo, jonka rinnalla nillä tuloksilla, joita saavutetaan historiallisen tutkimuksen taikka puhtaasti loogillisen ajattelun avulla, on täysin yhdenvertainen asema. ${ }^{12}$ Väestöteoria ja väestötilasto liittyvät liian läheisesti toisiinsa, jotta niitä voitaisiin käsitellä toisistaan täysin erillisinä. Sellainen menettely johtaisi vain tarpeettomiin toistoihin. Väestötieteen jakamista vain kahteen pääosaan, väestöteoriaan ja väestöpolitiikkaan, voidaan perustella silläkin seikalla, että myöskin kansantalous- ja finanssitieteissä erotetaan nämä kaksi puolta omistamatta ao. tilastoille mitään erikoisasemaa.

Väestötieteen työkenttä määriteltiin aikaisemmin suppeammaksi kuin nykyään. Rümelin esim. katsoi sen tehtäviin kuuluvan vain väestötilastosta saatavien tosiseikkojen yhdistämisen yleisiksi lausekkeiksi ja säännönmukaisuuksiksi. ${ }^{13}$ Samaan tapaan määrittelee väestöteorian tehtävät myös Most, ${ }^{14}$ joka lukee esim. väestön ammatillisen ja sosiaalisen rakenteen selvittämisen ja tutkimisen kuuluvan kansantalous- eikä väestö- 
tieteelle. ${ }^{15}$ Mutta, kuten Mombert on huomauttanut, väestötiede, joka tahtoo esittää ja tutkia väestökysymystä kokonaisuudessaan, ei voi olla ottamatta huomioon kaikkia niitä yhteiskunnallisen ja taloudellisen elämän puolia, jotka ovat syy-yhteydessä väestön tilan ja kehityksen kanssa. ${ }^{16}$ Mombert paneekin pääpainon juuri ns. taloudelliselle ja sosiologiselle väestöteorialle, jonka tehtävänä on selvitellä toisaalta sitä vaikutusta. mikä taloudellisilla ja yhteiskunnallisilla ilmiöillä, esim. talouselämän rakenne- ja suhdannevaihteluilla, omaisuuden ja työnjaolla, uskonnolla, lainsäädännöllä ym. tekijöillä on väestön tilaan ja kehitykseen, ja toisaalta sitä, miten nämä puolestaan vaikuttavat ensiksi mainittuihin. Tämän taloudellis-sosiologisen väestöteorian vastakohtana on sitten biologis-luonnontieteellinen väestöoppi, johon kuuluvat erilaiset luonnon luomista tekijöistä aiheutuvat, esim. väestön laatua koskevat kysymykset. Viimeksi mainittu muodostaisi edelliselle jonkinlaisen johdannon, samaan tapaan kuin kansantalouden oppikirjoissa on toisinaan tapana aloittaa esitys selostamalla talouden ilmastollisia, maantieteellisiä ym. edellytyksiä. Taloudellis-sosiologiseen väestöteoriaan nämä biologisista tekijöistä riippuvat kysymykset kuuluisivat vain sikäli, kuin niitä voidaan pitää taloudellisesti tai yhteiskunnallisesti tärkeinä. ${ }^{17}$

Vaikka väestötieteen tutkimuksen kohteena onkin eräs kansantaloudellisen tuotannon tekijä, työvoima, sitä ei silti voida pitää minään kansantaloustieteen osana, yhtä vähän kuin toista tuotannontekijää luontoa ja sen paljous- ja laatusuhteita selvittelevät tieteet meteorologia, geologia ym. sitä ovat, kuten Most huomauttaa. ${ }^{18}$ Kansantaloustieteen oppikirjoissa on kyllä tapana omistaa väestöä koskeville kysymyksille oma osastonsa, joka "väestöopin» nimellä on asetettu tuotantoa, vaihdantaa, jakaantumista ja kulutusta selvittelevien osien rinnalle. Tällaisista esityksistä saa kuitenkin sen vaikutelman, kuin tämä "väestöoppi" olisi muulle kokonaisuudelle vieras osa, joka paremman paikan puutteessa on sijoitettu tähän. ${ }^{19}$ Toisaalta on selvää, että kansantaloustieteen puitteissa väestön tilaa ja kehi- 
tystä koskevat kysymykset voivat tulla vain lyhyesti ja ylimalkaisesti käsitellyiksi. Väestötiede ei ole mikään kansantaloustieteen osa, vaan siihen rinnastettava yhteiskuntatieteen haara, joka on keskinäisessä vuorovaikutuksessa ensiksi mainitun kanssa. Tämä mielipide, jonka Rümelin ${ }^{20}$ esitti jo v. 1882 , on sittemmin saavuttanut yleisen hyväksymisen. ${ }^{21}$

Väestötieteellä on liittymäkohtia moneen muuhunkin tieteeseen kuin kansantaloustieteeseen ja sosiologiaan. Koska sen tutkimuksen kohteena olevat seikat kuuluvat menneisyyteen, se on eräässä mielessä historiaa. Mutta yhtä hyvin se voi olla myös maantiedettä, koska ne yhteisöt, joita se tutkii, tavallisesti ovat alueellisia, määrättyyn paikkaan liittyviä. Samalla tavalla kuin puhumme esim. taloushistoriasta tai talousmaantieteestä taikka poliittisesta historiasta ja poliittisesta maantieteestä, voimme puhua myöskin väestöhistoriasta ja väestömaantieteestä.

Väestötieteellä on myöskin liittymäkohtia biologiaan, sillä ovathan ne kaksi seikkaa, joista luonnollinen väenlisäys johtuu, syntymä ja kuolema, biologisia tekijöitä. Samoin on asian laita psykologiaan nähden. Monet kuolemantapaukset, etenkin tapot ja itsemurhat, johtuvat psykologisista syistä, joilla sitäpaitsi on suuri vaikutuksensa myös syntyvyyden rajoittamiseen, muuttoliikkeeseen ym. ${ }^{22}$

Muista väestötieteen aputieteistä on ennen muita mainittava tilastotiede, jolle se on suuressa kiitollisuudenvelassa kehityksestään. Voidaanpa sanoa, että vasta väestötilaston sekä tilastollisten menettelytapojen kehityminen on luonut edellytykset itsenäisen väestötieteen syntymiselle.

Lopuksi vielä muutama sana väestöteorian ja väestöpolitiikan välisestä suhteesta. Kuten edellä jo on viitattu, viimeksi mainitun tehtävät määräytyvät niiden ilmiöiden mukaan, joita teoreettinen tutkimus kykenee väestön tilassa ja kehityksessä osoittamaan. Väestöpolitiikka on siis väestöteorian sovellettu osa. Mutta toisaalta on huomattava, että tällä kuten monen muunkin 
tieteen alalla teoreettinen harkinta ja tutkimus on saanut ensimmäisen virikkeensä käytännöllisen elämän päivänkysymyksistä. Väestöpolitiikka oli olemassa jo paljon aikaisemmin, kuin väestötieteestä voitiin edes vaatimattomimmassakaan mielessä puhua.

\section{Kirjallisuusviitteitä.}

1 Eräänä siihen viittaavana seikkana voidaan mainita esim. se, että kun H. Harmsenin alulle panema aikakauskirja »Archiv für Bevölkerungspolitik, Sexualethik und Familienkunde» vuoden 1934 alussa uusittiin, sen nimeksi tuli `Archiv für Bevölkerungswissenschaft und Bevölkerungspolitik».

2 Landry, Adolphe, Traité de démographie, Pariisi 1945, s. 7.

3 Katso esim. Wolfes A. B., Demography. Encyclopaedia of the Social Sciences, edited by Edwin R. A. Seligman, Volume V, Lontoo 1931, ss. $85-86$.

${ }^{4}$ Katso esim. Burgdörfer, $F$., Volkskunde im Lichte der Bevölkerugsstatistik und Bevölkerungspolitik, Archiv für Bevölkerungswissenschaft und Bevölkerungspolitik 1936, s. 203.

5 Iso tietosanakirjamme määrittelee sen lyhyesti ja puutteellisesti seuraavasti: $\gg$ Demografia, oik. kansankuvaus; väestötilasto». Tämä selitys on siis ristiriitainen $» v \ddot{a}$ estöoppi»-sanan selityksen kanssa, jonka mukaan demografia on yhtä kuin väestöoppi.

6 Landry, mt., ss. 7-12; Vincent, Paul, Une nouvelle revue de démographie: »Population Studies». Population 1947, n:o 4, s. 775 ym.

7 Mombert, Paul, Bevölkerunslehre, Jena 1929, ss. 2-3.

8 Rümelin, Gustav, Die Bevölkerunslehre, Handbuch der politischen Oekonomie, herausgegeben von G. Schönberg, I Band, Tübingen 1882, ss. $1204-1205$.

9 Wagner, Adolf, Grundlegung der politischen Oekonomie, 3. Aufl., Leipzig 1893, s. 446.

10 Most, Otto, Bevölkerungswissenschaft, Leipzig 1913, s. 8.

11 Mombert, mt., s. 3, ja sama, Das Gebiét der Bevölkerungslehre und ihre Stellung im Rahmen der Sozialwissenschaften. Jahrbücher für Nationalökonomie und Statistik, Band 114, 1920, ss. 409-410.

12 Mombert 1929 , s. 2.

13 Rümelin, mt., s. 1204.

14 Most, mt., s. 7.

15 Most, mt., s. 10.

16 Mombert 1920 , ss. $416-417$.

17 Mombert 1929, ss. 4 -6; 1920, s. 411.

18 Most, mt., s. 6.

19 Mombert 1920 , s. $407 ; 1929$, s. 8.

20 Rümelin, mt., s. 1204.

${ }^{21}$ Katso esim. Wagner, mt., s. 446, Mombert ym.

22 Landry, mt., ss. 10-11. 